\title{
Community structure and vertical distribution of oncaeid copepods in Tosa Bay, southern Japan
}

\author{
YUICHIRO NISHIBE ${ }^{1,2}$, YUUICHI HIROTA ${ }^{3}$ AND HIROSHI UEDA ${ }^{4}$ \\ ${ }^{1}$ Center for Marine Environmental Studies, Ehime University, 3 Bunkyo-cho, Matsuyama 790-8577, Japan, ${ }^{2}$ Present address: Ocean \\ Research Institute, University of Tokyo, 1-15-1 Minamidai, Nakano, Tokyo 164-8639, Japan, ${ }^{3}$ National Research Institute of \\ Fisheries Science, Fisheries Research Agency, 6-1-21 Sanbashi-dori, Kochi 780-8010, Japan, ${ }^{4}$ Usa Marine Biological Institute, \\ Kochi University, 194 Inoshiri, Usa, Tosa 781-1164, Japan
}

\begin{abstract}
Community structure and vertical distribution of oncaeid copepods were investigated at an offshore site in Tosa Bay, southern Japan. Samples were collected with a $0.063 \mathrm{~mm}$ closing type net from eight discrete layers between the surface and $500 \mathrm{~m}$ depth in August and November 2005. A total of 45 species and three form variants belonging to the genera Triconia, Oncaea, Spinoncaea, Conaea and Epicalymma were identified. The greatest number of species was consistently found in the lower epipelagic zone, at 50-100 $\mathrm{m}$. The vertical distribution patterns of oncaeid copepods were similar between August and November, with the highest abundances in the upper epipelagic zone above the thermocline. The oncaeid maxima corresponded with the depth where appendicularians occurred in high numbers. Dominant species in the water column $(0-500 \mathrm{~m})$ were O. venusta small form, O. media, O. scottodicarloi, O. waldemari, O. zernovi, O. tregoubovi, S. ivlevi, S. tenuis and $\mathrm{T}$. conifera. The vertical succession of species composition was almost the same between August and November, although several species showed a downward shift of their depth-range to some extent in November. The oncaeid copepod community could be differentiated into three distinct groups according to the depth layers, each corresponding to different hydrographic conditions in the water column.
\end{abstract}

Keywords: Copepoda, Oncaeidae, community structure, vertical distribution

Submitted 12 May 2008; accepted 9 September 2008; first published online 16 April 2009

\section{INTRDDUCTION}

The cyclopoid family Oncaeidae is one of the most diverse taxa of marine pelagic copepods (Boxshall \& Halsey, 2004). They exhibit a ubiquitous distribution throughout the world oceans, ranging from tropical to polar regions (Malt, 1983 for a review) and from the surface to bathypelagic depths (e.g. Boxshall, 1977; Böttger-Schnack, 1994; Nishibe \& Ikeda, 2004). Species of this family are small, usually less than $1.0 \mathrm{~mm}$ in body length as adults (Malt, 1983; Böttger-Schnack et al., 2004). Recent investigations using appropriate net meshes of $0.1 \mathrm{~mm}$ or finer have shown that the oncaeids highly dominate the copepod communities in terms of abundance, especially in oceanic midwater and deep water (e.g. Böttger-Schnack, 1996, 1997; Yamaguchi et al., 2002). The oncaeids are known to be loosely associated with discarded houses of appendicularians (Alldredge, 1972; Ohtsuka et al., 1993; Steinberg et al., 1994). They feed on phytoplankters and protists remaining on the houses, as well as on the actual membranes and incurrent filters of the houses (Ohtsuka \& Kubo, 1991; Ohtsuka et al., 1996). Because of their high numerical abundance and substrate-feeding

Corresponding author:

Y. Nishibe

Email: nishibe@ori.u-tokyo.ac.jp behaviour, oncaeids may play important trophic roles which are considerably different from those of suspension-feeding calanoids.

Information about the species composition and vertical distribution of oncaeid copepods is still scarce for the western North Pacific and its adjacent waters as compared to other regions of the world ocean. Tsalkina (1977) investigated the vertical distribution and diel vertical migration of some oncaeid species in the upper $500 \mathrm{~m}$ of the tropical North Pacific and the Sulu Sea. Several studies have also provided data on the depth-distribution pattern of oncaeids (Furuhashi, 1966; Minoda, 1971; Hirakawa et al., 1990; Lo et al., 2004). Itoh \& Mizushima (1999) reported the seasonal distribution of oncaeid copepods at a coastal site in Suruga Bay, central Japan. By using coarse nets with $0.2-0.3 \mathrm{~mm}$ meshes, however, all of these studies were unable to include quantitative data on smaller oncaeid species $(<0.5 \mathrm{~mm}$ in body length), which generally account for a large proportion of total number of oncaeids (e.g. Böttger-Schnack, 1990, 1997). Nishibe \& Ikeda (2004) studied the vertical structure of the oncaeid copepod community, including the abundant smaller species, in the upper $2000 \mathrm{~m}$ of the Oyashio region, western subarctic Pacific by analysing samples taken with nets of $0.1 \mathrm{~mm}$ mesh size.

The present study investigates and compares the community structure and vertical distribution of oncaeid copepods collected with a net of $0.063 \mathrm{~mm}$ mesh size from the upper $500 \mathrm{~m}$ at an 
offshore site of Tosa Bay, located on the Pacific coast of southern Japan, between samples taken in August and November 2005. The results are compared with published data based on finemesh net samples from the other oceanic regions. The depthdistribution of appendicularians is also examined in order to compare with that of oncaeid copepods. Vertical differences in the oncaeid copepod community are discussed in relation to the hydrographic conditions in the water column.

\section{MATERIALS AND METHDDS}

Tosa Bay has a wide mouth open to the Pacific Ocean, with a narrow continental shelf $(10-20 \mathrm{~km})$ and steep slope that falls to depths greater than $800 \mathrm{~m}$ (Figure 1). The hydrographic conditions of the bay are strongly influenced by the Kuroshio Current (Miyata et al., 1985; Fujimoto, 1987), the western boundary current of the North Pacific subtropical gyre, flowing eastward off just south of Shikoku, Japan.

Zooplankton samples were collected on 4 August and 3 November 2005 on board the RV 'Shirafuji-Maru' at a station $\left(33^{\circ} 12^{\prime} \mathrm{N} 133^{\circ} 48^{\prime} \mathrm{E}, 700 \mathrm{~m}\right.$ deep) located on the shelf slope region of Tosa Bay (Figure 1). A closing type net $(36 \mathrm{~cm}$ mouth diameter, $0.063 \mathrm{~mm}$ mesh size; Itoh \& Mochioka, 2005) was hauled vertically at a speed of $0.5 \mathrm{~m} \mathrm{~s}^{-1}$ from eight discrete layers: $0-20,20-50,50-100,100-150$, $150-200,200-300,300-400$ and $400-500 \mathrm{~m}$. All samplings were carried out in the daytime (11:00-14:30 in local time). The volume of water filtered was estimated from the reading of a flow meter (Rigosha) mounted inside the mouth of the net. The depth the net reached was estimated from the wire angle and wire paid out. After collection, samples were preserved immediately on board ship in a $2 \%$ formaldehyde-seawater solution buffered with borax. Vertical profiles of temperature and salinity were determined simultaneously by using a CTD system (Integrated CTD, Falmouth Scientific, Inc.). Water samples for measurement of chlorophyll- $a$ concentration were collected with 1.71 Niskin bottles mounted on a rosette multisampler from depths of 10, 20,30,40,50,60,80,100, 150 and $200 \mathrm{~m}$. Surface water was collected with a plastic bucket. A $400 \mathrm{ml}$ portion of each water sample was filtered onto a Whatman

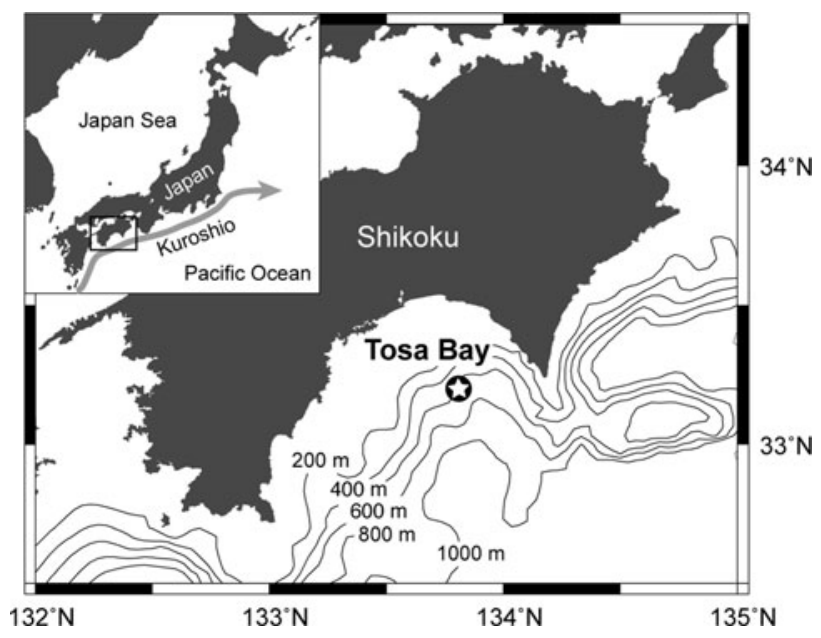

Fig. 1. Location of sampling site (circled star) in Tosa Bay, southern Japan, with bathymetric isolines $(200,400,600,800$ and $1000 \mathrm{~m})$.
GF/F filter. Each sample collected on a filter was extracted in $8 \mathrm{ml}$ of $90 \%$ acetone for 24 hours, and chlorophyll- $a$ concentration was then determined with a fluorometer (10-AU, Turner Designs).

The oncaeid copepods (adults and copepodid stages) were sorted from the entire sample or aliquots (from $1 / 2$ to $1 / 8$ ) taken by using a box type splitter (Motoda, 1959). About 200-1000 individuals per sample were enumerated under a stereomicroscope. The abundance of appendicularians was assessed from the entire sample or aliquots (from $1 / 2$ to $1 / 16$ ). Taxonomic identification of oncaeid copepods was made only for adults (CVI females and males); immature copepodid stages (CI-CV) of all oncaeid species were pooled without identification and counted as Oncaea spp. juveniles. The adult females and males were counted separately. Species identification followed Shmeleva (1969), Gordeyeva (1972, 1973), Heron (1977), Kršinić \& Malt (1985), Boxshall \& Böttger (1987), Böttger-Schnack \& Boxshall (1990), Heron \& Bradford-Grieve (1995), Böttger-Schnack (1999, 2001, 2002, 2003, 2005) and Huys \& Böttger-Schnack (2007). A more detailed microscopic examination with dissection was conducted for identification of some sibling species of smaller species. According to the description given in Böttger-Schnack \& Huys (2004), female O. venusta were separated into distinct forms by their body length and presence/absence of a dorsal swelling on the second pediger. Male O. venusta were assigned to the forms merely by their body size. Undescribed Triconia sp. and Oncaea sp., which could clearly be distinguished by morphological characters, were treated as separate taxa.

To examine the seasonal and vertical differences in community structure of oncaeid copepods, we conducted cluster analysis and non-metric multidimensional scaling (MDS) ordination based on species abundance data, using the software package Primer 5 (Primer-E Ltd.). Abundance data (ind $\mathrm{m}^{-3}$ ) of each oncaeid species were transformed by log $(\mathrm{x}+1)$ values prior to analysis, in order to reduce the bias of very abundant species. The Bray-Curtis index was used to examine the similarities of abundance and species composition between samples. For grouping the samples, similarity indices were coupled with hierarchical agglomerative clustering with the unweighted pair-group method using arithmetic means (UPGMA). The MDS ordination was carried out to delineate the sample groups on the two-dimensional map.

RESULTS

\section{Hydrography}

Surface temperatures were $28.4^{\circ} \mathrm{C}$ in August and $24.5^{\circ} \mathrm{C}$ in November (Figure $2 \mathrm{~A}$ ). The vertical profiles of temperature showed a strong thermal stratification of the water column in both sampling months; the seasonal thermoclines were well established at 20-70 m depth in August and 70-150 m depth in November. In August, low-salinity water $(<34.0)$ was observed near the surface (Figure $2 \mathrm{~B}$ ), possibly due to the inflows of river water into the bay. The salinity maxima $(\sim 34.6)$, influenced by the offshore Kuroshio Current, were seen at $55 \mathrm{~m}$ in August and $120 \mathrm{~m}$ in November. Below $170 \mathrm{~m}$ depth, there were no apparent differences in the temperatures $\left(5.5-11.0^{\circ} \mathrm{C}\right)$ and salinities $(34.2-34.4)$ between August and November. Chlorophyll- $a$ concentrations 
A

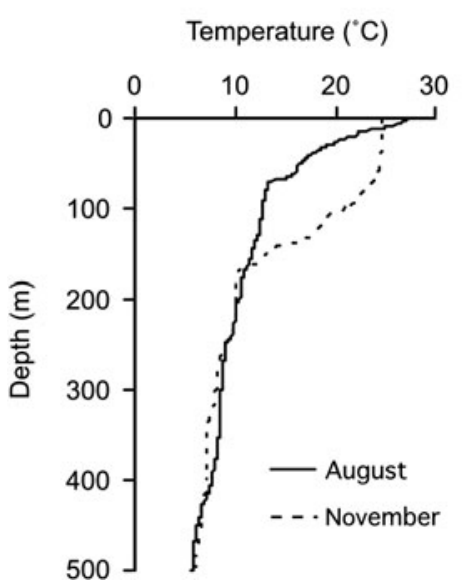

B

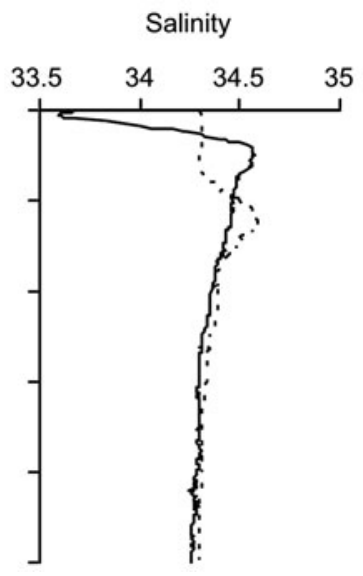

C

\section{Chlorophyll a $\left(\mu \mathrm{gl}^{-1}\right)$}

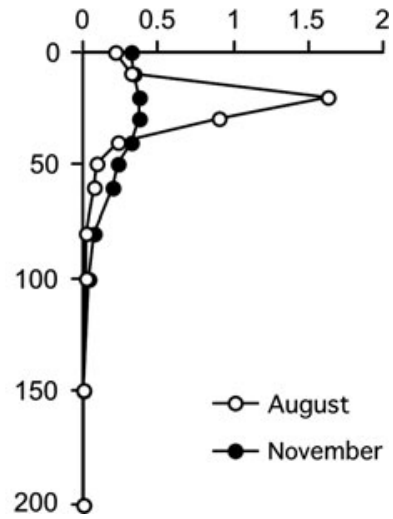

Fig. 2. Vertical profiles of (A) temperature, (B) salinity and (C) chlorophyll-a concentration at the sampling site in Tosa Bay in August and November 2005. Note the different depth scales.

showed a conspicuous peak at $20 \mathrm{~m}$ depth in August, but were more homogeneous between the surface and $40 \mathrm{~m}$ depth in November (Figure $2 \mathrm{C}$ ).

\section{Appendicularians}

The maximum abundances of appendicularians were found in the shallowest layer $(0-20 \mathrm{~m})$, reaching 4140 and 2180 ind $\mathrm{m}^{-3}$ in August and November, respectively. Below $50 \mathrm{~m}$ (August) or $100 \mathrm{~m}$ (November) depth, the abundances of appendicularians decreased substantially, with densities being less than 20 ind $\mathrm{m}^{-3}$.

\section{Species richness and taxonomic accounts}

The present study identified five genera, Triconia, Oncaea, Spinoncaea, Conaea and Epicalymma, and 45 species including two as yet undescribed morphotypes of Triconia and Oncaea (Table 1). Three form variants (small, medium and large) of $O$. venusta were distinguished by the size and presence/absence of the prosomal dorsal swelling (Table 2). The small and large forms were collected in both August and November, whereas the medium form was found only in November (Table 1). Of the two undescribed species, Triconia sp. (body length: $0.62 \mathrm{~mm}$ in female) was similar to T. rufa Boxshall \& Böttger, but differed by the length ratio of the outer distal spine to the conical projection on the endopods of the legs 2 and 3 and by the absence of the small dorso-posterior projection on the second pediger. Oncaea sp. (body length: $0.36 \mathrm{~mm}$ in female and $0.31 \mathrm{~mm}$ in male) was similar to O. parabathyalis Böttger-Schnack in habitus and in leg armature, but differed in body size. This species might belong to the setosa- or lacinia-group of the family Oncaeidae (cf. Böttger-Schnack, 2005). Species of Epicalymma were not identified further due to their small size. Of a total of 48 taxa, including the three form variants of $O$. venusta, 37 were found to be common to both August and November (Table 1). The vertical patterns of the number of oncaeid species were fairly similar between the two months (Figure 3): in both months the number increased from the surface to maximal values of more than 20 species at 50-100 m, and were more or less constant below that depth.

\section{Abundance and species composition}

Abundance of oncaeid copepods showed maximal values in the upper part of the epipelagic zone $(0-20 \mathrm{~m}$ in August and $20-50 \mathrm{~m}$ in November) above the thermocline, reaching 1200 and 1100 ind $\mathrm{m}^{-3}$ in August and November, respectively, and then gradually decreased by more than one order of magnitude by $200 \mathrm{~m}$ depth (Figure 4). Below that depth, their abundances were more or less constant with lower values. In the water column from o to $500 \mathrm{~m}$ depth, the abundance of total oncaeid copepods in November $(105,800$ ind $\mathrm{m}^{-2}$ ) was about twice as high as that in August $(64,200$ ind $\mathrm{m}^{-2}$ ) (Table 1 ). Oncaea spp. juveniles accounted for about half of the total number of oncaeids in both August and November (Table 1).

The species composition and abundance of individual species in the water column from o to $500 \mathrm{~m}$ depth are given in Table 1. Dominant species, each contributing more than $1 \%$ of the total abundances in both August and November, were Triconia conifera, Oncaea venusta small form, O. media, O. scottodicarloi, O. waldemari, O. zernovi, O. tregoubovi, Spinoncaea ivlevi and S. tenuis. Oncaea venusta medium form was not observed in August, but became one of the most abundant species in November (3.5\% of the total). Oncaea venusta large form and O. bispinosa also showed a much higher relative abundance in November $(\sim 5 \%)$ than in August $(\sim 0.5 \%)$. Several deepwater oncaeid species, such as O. englishi, O. ornata, O. shmelevi, O. brodskii, O. longiseta and O. macilenta, were recorded only in November, although their contribution to the total number was low $(<0.1 \%)$.

The community structure of adult oncaeid copepods varied considerably according to the depth layers in both August and November (Figure 5). In August Oncaea venusta small form, $O$. media and O. waldemari predominated in the upper epipelagic zone above the thermocline ( $0-20 \mathrm{~m})$, each comprising more than $20 \%$ of the total number of adults (Figure $5 \mathrm{~A}$ ). Within the thermocline $(20-50 \mathrm{~m})$, O. scottodicarloi became the most abundant species, although the above mentioned species remained abundant in this depth layer. In the lower epipelagic zone between 50 and $200 \mathrm{~m}$, very small species O. zernovi and Spinoncaea tenuis were highly abundant, accounting for $15-45 \%$ and $10-30 \%$, respectively, of the 
Table 1. Abundance $\left(\mathrm{N}\right.$ : ind $\left.\mathrm{m}^{-2}\right)$ of oncaeid copepods in the $0-500 \mathrm{~m}$ water column at the sampling site in Tosa Bay. Proportional abundance (\%) of each species to the total is also shown. F, females; M, males; - , no individuals.

\begin{tabular}{|c|c|c|c|c|c|}
\hline \multirow[t]{2}{*}{ Taxa } & \multirow[t]{2}{*}{ Sex/stage } & \multicolumn{2}{|c|}{ August } & \multicolumn{2}{|c|}{ November } \\
\hline & & $\mathbf{N}$ & $\%$ & $\mathbf{N}$ & $\%$ \\
\hline \multicolumn{6}{|l|}{ Triconia } \\
\hline T. conifera $^{\mathrm{a}, \mathrm{b}}$ & $\mathrm{F}, \mathrm{M}$ & 1000 & 1.6 & 1080 & 1.0 \\
\hline T. derivata ${ }^{\mathrm{a}}$ & $\mathrm{F}$ & 17 & $<0.1$ & - & \\
\hline T. furcula ${ }^{\mathrm{a}}$ & $\mathrm{F}, \mathrm{M}$ & 54 & $<0.1$ & 45 & $<0.1$ \\
\hline T. redacta $a^{\mathrm{a}, \mathrm{b}}$ & $\mathrm{F}, \mathrm{M}$ & - & & 45 & $<0.1$ \\
\hline T. similis $^{\mathrm{a}, \mathrm{b}}$ & $\mathrm{F}, \mathrm{M}$ & 173 & 0.3 & 153 & 0.1 \\
\hline T. parasimilis $^{\mathrm{b}}$ & $\mathrm{F}, \mathrm{M}$ & 206 & 0.3 & 16 & $<0.1$ \\
\hline T. hawii & $\mathrm{F}$ & 18 & $<0.1$ & - & \\
\hline T. minuta $a^{\mathrm{a}, \mathrm{b}}$ & $\mathrm{F}, \mathrm{M}$ & 426 & 0.7 & 371 & 0.4 \\
\hline T. umerus ${ }^{\mathrm{b}}$ & $\mathrm{F}, \mathrm{M}$ & 189 & 0.3 & 233 & 0.2 \\
\hline T. dentipes ${ }^{\mathrm{a}, \mathrm{b}}$ & $\mathrm{F}, \mathrm{M}$ & 121 & 0.2 & 512 & 0.5 \\
\hline T. elongata & $\mathrm{F}, \mathrm{M}$ & 194 & 0.3 & 168 & 0.2 \\
\hline T. giesbrechti ${ }^{\mathrm{b}}$ & $\mathrm{F}$ & 10 & $<0.1$ & 25 & $<0.1$ \\
\hline Triconia sp. & F, M & 690 & 1.1 & 143 & 0.1 \\
\hline \multicolumn{6}{|l|}{ Oncaea s. str. } \\
\hline \multirow{3}{*}{$\begin{aligned} & \text { O. } \text { venusta }^{\mathrm{a}, \mathrm{b}} \text { small form } \\
& \text { medium form } \\
& \text { large form }\end{aligned}$} & $\mathrm{F}, \mathrm{M}$ & 1420 & 2.2 & 5950 & 5.6 \\
\hline & $\mathrm{F}, \mathrm{M}$ & - & & 3700 & $3 \cdot 5$ \\
\hline & $\mathrm{F}, \mathrm{M}$ & 332 & 0.5 & 5050 & 4.8 \\
\hline O. mediterranea $a^{\mathrm{a}, \mathrm{b}}$ & $\mathrm{F}, \mathrm{M}$ & 1300 & 2.0 & 874 & 0.8 \\
\hline O. media $^{\mathrm{a}, \mathrm{b}}$ & $\mathrm{F}, \mathrm{M}$ & 1110 & 1.7 & 4100 & 3.9 \\
\hline O. scottodicarloi $i^{\mathrm{a}, \mathrm{b}}$ & $\mathrm{F}, \mathrm{M}$ & 4060 & 6.3 & 1610 & 1.5 \\
\hline O. waldemari & $\mathrm{F}, \mathrm{M}$ & 1360 & 2.1 & 2220 & 2.1 \\
\hline O. clevei $^{\mathrm{a}, \mathrm{b}}$ & F, M & 361 & 0.6 & 2430 & 2.3 \\
\hline \multicolumn{6}{|l|}{ Oncaea } \\
\hline O. bispinosa & $\mathrm{F}, \mathrm{M}$ & 447 & 0.7 & 4360 & 4.1 \\
\hline O. zernovi ${ }^{\mathrm{a}, \mathrm{b}}$ & $\mathrm{F}, \mathrm{M}$ & 5740 & 8.9 & 2850 & 2.7 \\
\hline O. atlantica & $\mathrm{F}, \mathrm{M}$ & 631 & 1.0 & 447 & 0.4 \\
\hline O. vodjanitskii & $\mathrm{F}, \mathrm{M}$ & 58 & $<0.1$ & 1180 & 1.1 \\
\hline O. minima & $\mathrm{F}, \mathrm{M}$ & 421 & 0.7 & 597 & 0.6 \\
\hline O. crypta & $\mathrm{F}, \mathrm{M}$ & 747 & 1.2 & 660 & 0.6 \\
\hline O. parabathyalis & F, M & 451 & 0.7 & 966 & 0.9 \\
\hline O. ovalis $^{\mathrm{b}}$ & $\mathrm{F}, \mathrm{M}$ & 76 & 0.1 & 85 & $<0.1$ \\
\hline O. tregoubovi ${ }^{\mathrm{b}}$ & $\mathrm{F}, \mathrm{M}$ & 985 & 1.5 & 1610 & 1.5 \\
\hline O. prendeli & $\mathrm{F}, \mathrm{M}$ & 88 & 0.1 & 952 & 0.9 \\
\hline O. longipes ${ }^{\mathrm{b}}$ & F, M & 85 & 0.1 & 786 & 0.7 \\
\hline O. parila ${ }^{\mathrm{b}}$ & $\mathrm{F}, \mathrm{M}$ & 49 & $<0.1$ & 528 & 0.5 \\
\hline O. english $i^{\mathrm{b}}$ & $\mathrm{F}, \mathrm{M}$ & - & & 36 & $<0.1$ \\
\hline O. ornata ${ }^{\mathrm{a}}$ & $\mathrm{F}, \mathrm{M}$ & - & & 30 & $<0.1$ \\
\hline O. shmelevi & $\mathrm{F}$ & - & & 54 & $<0.1$ \\
\hline O. brodskii ${ }^{\mathrm{b}}$ & $\mathrm{F}$ & - & & 18 & $<0.1$ \\
\hline O. infantula & $\mathrm{F}$ & 9 & $<0.1$ & 30 & $<0.1$ \\
\hline O. longiseta & $\mathrm{F}$ & - & & 24 & $<_{0.1}$ \\
\hline O. macilenta ${ }^{\mathrm{b}}$ & $\mathrm{F}$ & - & & 9 & $<0.1$ \\
\hline O. memorata & $\mathrm{F}$ & 13 & $<0.1$ & - & \\
\hline O. oceanica & $\mathrm{F}, \mathrm{M}$ & 9 & $<0.1$ & 72 & $<0.1$ \\
\hline Oncaea sp. & $\mathrm{F}, \mathrm{M}$ & 45 & $<0.1$ & 383 & 0.4 \\
\hline \multicolumn{6}{|l|}{ Spinoncaea } \\
\hline S. ivlevi & $\mathrm{F}, \mathrm{M}$ & 984 & 1.5 & 3230 & 3.1 \\
\hline S. humesi & $\mathrm{F}, \mathrm{M}$ & 297 & 0.5 & 671 & 0.6 \\
\hline S. tenuis ${ }^{\mathrm{b}}$ & $\mathrm{F}, \mathrm{M}$ & 2720 & 4.2 & 2810 & 2.7 \\
\hline \multicolumn{6}{|l|}{ Other Oncaeidae } \\
\hline Conaea rapax ${ }^{\mathrm{a}, \mathrm{b}}$ & $\mathrm{F}, \mathrm{M}$ & 9 & $<0.1$ & 152 & 0.1 \\
\hline Epicalymma spp. ${ }^{\mathrm{b}}$ & $\mathrm{F}, \mathrm{M}$ & 79 & 0.1 & 362 & 0.3 \\
\hline Oncaea spp. unidentified & M & - & & 184 & 0.2 \\
\hline Oncaea spp. juveniles & $<\mathrm{C}_{5}$ & 37200 & 58 & 54000 & 51 \\
\hline Total abundance & & 64200 & & 105800 & \\
\hline
\end{tabular}

${ }^{\mathrm{a}}$ and ${ }^{\mathrm{b}}$ indicate the species have previously been recorded in the Kuroshio and Oyashio regions, respectively (see text for details).
Table 2. Body length (mm) of form variants of Oncaea venusta in Tosa Bay. The presence/absence of dorsal swelling on the second pediger of female specimen is also shown. $\mathrm{N}$, number of individuals examined.

\begin{tabular}{lllll}
\hline Form variants & Sex & N & Total body length $(\mathbf{m m})$ & Dorsal swelling \\
\hline Small & Female & 35 & $0.89-1.04$ & Present \\
& Male & 65 & $0.57-0.73$ & \\
\multirow{2}{*}{ Medium } & Female & 20 & $0.98-1.14$ & Absent \\
& Male & 21 & $0.78-0.88$ & \\
Large & Female & 21 & $1.25-1.41$ & Absent \\
& Male & 30 & $0.94-1.09$ & \\
\hline
\end{tabular}

total oncaeids. Several Triconia species, such as T. minuta, T. umerus, T. dentipes, T. elongata and Triconia sp. occurred in this depth zone, although their combined contribution to the total number was relatively low $(<10 \%)$. Below $200 \mathrm{~m}$ depth, the species compositions were almost the same between the depth layers sampled. Most numerous in this mesopelagic zone were O. crypta, O. parabathyalis, O. minima, O. tregoubovi, O. prendeli, O. longipes and T. conifera.

In November, the dominant species and their vertical succession were almost identical to those observed in August (Figure 5B), although several species (e.g. Oncaea venusta small and large forms, O. media, O. waldemari, O. crypta, O. parabathyalis, O. tregoubovi and Spinoncaea ivlevi) tended to show a downward shift of their depth-range of distribution as compared to August. In the epipelagic zone, the relative importances of O. venusta medium form, O. bispinosa and $S$. ivlevi were higher in November than in August, whereas those of $O$. scottodicarloi and $O$. zernovi were much lower.

\section{Community analysis}

The 16 samples could be separated into two distinct groups by cluster analysis at the similarity level of $10 \%$, according

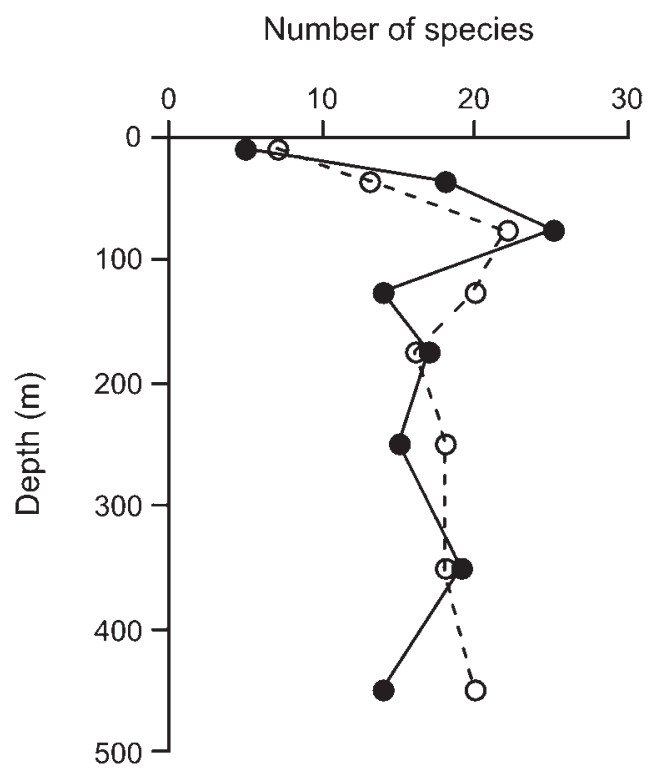

Fig. 3. Vertical distribution of the number of species of oncaeid copepods at the sampling site in Tosa Bay in August (closed circle) and November 2005 (open circle). Epicalymma spp. and each form variant of Oncaea venusta are counted as one species. 


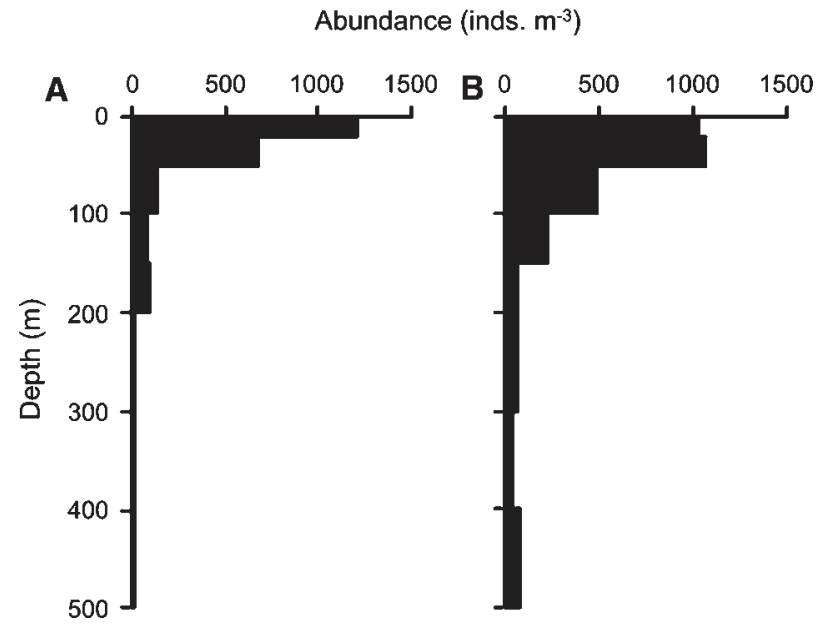

Fig. 4. Vertical distribution of abundance of oncaeid copepods at the sampling site in Tosa Bay in (A) August and (B) November 2005.

to sampling depth layers (Figure 6A). The first group (Group 1) comprised three samples collected from the upper epipelagic zone above the thermocline in August $(0-20 \mathrm{~m})$ and November $(0-20$ and $20-50 \mathrm{~m})$. The second group (Group 2) consisted of the remaining 13 samples and was further divided into two subgroups, Group $2 \mathrm{a}$ and $2 \mathrm{~b}$, at the similarity level of $20 \%$. Group 2 a included the samples collected from the lower epipelagic zone within or below the thermocline (20-50, 50-100, 100-150 and 150-200 m in August and $50-100$ and $100-150 \mathrm{~m}$ in November), while Group $2 \mathrm{~b}$ contained all samples from the mesopelagic zone (200$500 \mathrm{~m}$ ), with one exception from the lower epipelagic zone $(150-200 \mathrm{~m})$ in November. Samples from the same depth layer but on different months were grouped together in a single group or subgroup, except for those from $20-50 \mathrm{~m}$ and 150-200 m. Hence, the vertical changes in abundance and species composition appeared to be more pronounced than the seasonal difference between August and November. The arrangement of the samples according to sampling depth layers was also reflected on the MDS ordination plot (Figure 6B), thereby confirming the results of cluster analysis. The upper epipelagic samples (Group 1) were clearly separated from the lower epipelagic and mesopelagic samples (Groups $2 \mathrm{a}$ and $2 \mathrm{~b}$ ) on the MDS ordination plot.

\section{DISCUSSIDN}

A total of 45 species of four genera and one genus (Epicalymma) were identified from the $0-500 \mathrm{~m}$ water column in Tosa Bay. The number of species is much higher than that previously reported in the Kuroshio region from east of the Philippines to east of Honshu, Japan, where 20 species of oncaeid copepods have so far been recorded (Chen et al., 1974; Hirota, 1995; Itoh, 1997; Itoh \& Mizushima, 1999). Of the 43 known species identified in the present study, 15 have been recorded in the region, although earlier records of some of them (e.g. Oncaea zernovi, Triconia dentipes and $T$. similis) may have included their sibling species (O. bispinosa, T. elongata/T. giesbrechti, and T. parasimilis), which have been recently described (cf. Böttger-Schnack, 1999, 2002). Four species, O. curta, O. notopus, O. tenella and Monothula subtilis, listed by Hirota (1995) were not found in the present study. Instead, for three of them their sibling species (O. media/O. scottodicarloi/O. waldemari for O. curta, O. parila for O. notopus, and $O$. zernovi/O. bispinosa for O. tenella) were identified. The large number of oncaeid species in the present study is partly attributable to the finer mesh net used, since many of the newly recorded species are small in size $(<0.5 \mathrm{~mm}$ in body length). Furthermore, this is also a result of the better taxonomic resolution by taking into account the latest findings in oncaeid species differentiation in the present study.

The species diversity of oncaeid copepods in Tosa Bay is similar to or even higher than that obtained with fine-mesh net samples from other tropical and warm-temperate oceanic areas, such as the Red Sea (47 species from 0-1650 m; Böttger-Schnack et al., 2004), the eastern Mediterranean Sea

A

B

\section{Composition (\%)}
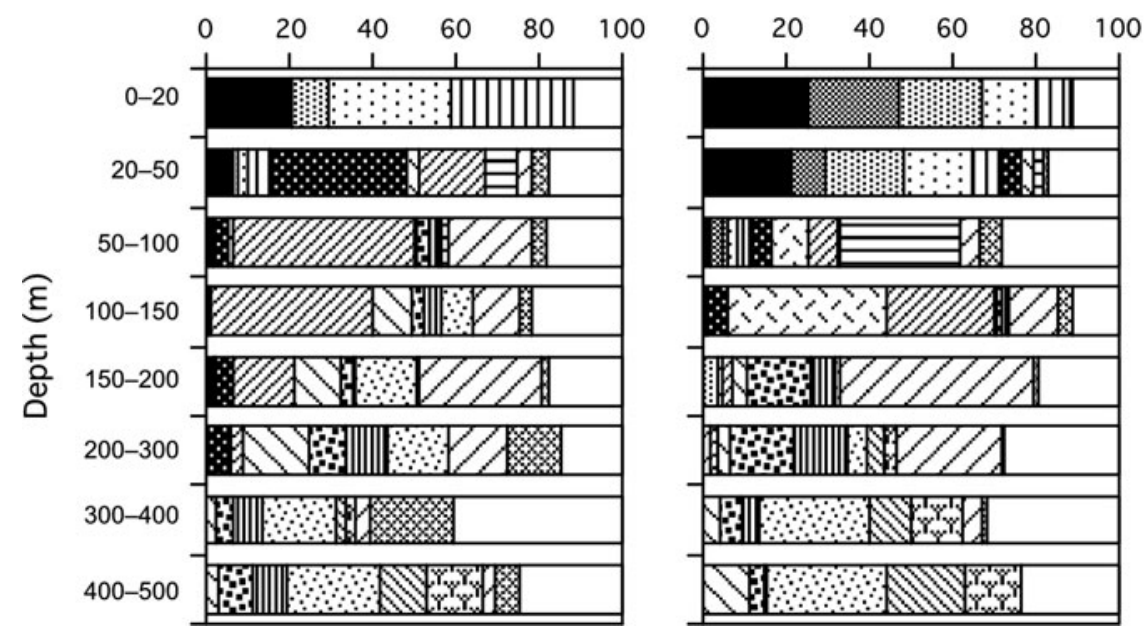

\begin{tabular}{|ll|}
\hline O. venusta small \\
O. venusta medium \\
O. venusta large \\
O. media \\
O. waldemari \\
O. scottodicarloi \\
O. bispinosa \\
O. zernovi \\
O. crypta \\
O. parabathyalis \\
O. minima \\
O. tregoubovi \\
O. prendeli \\
O. longipes \\
S. ivlevi \\
S. tenuis \\
T. conifera \\
$\square$ Others \\
\hline
\end{tabular}

Fig. 5. Vertical community structure of adult oncaeid copepods at the sampling site in Tosa Bay in (A) August and (B) November 2005. Only species contributing more than $10 \%$ to the total abundance of adults at least at one depth layer are considered. 
A
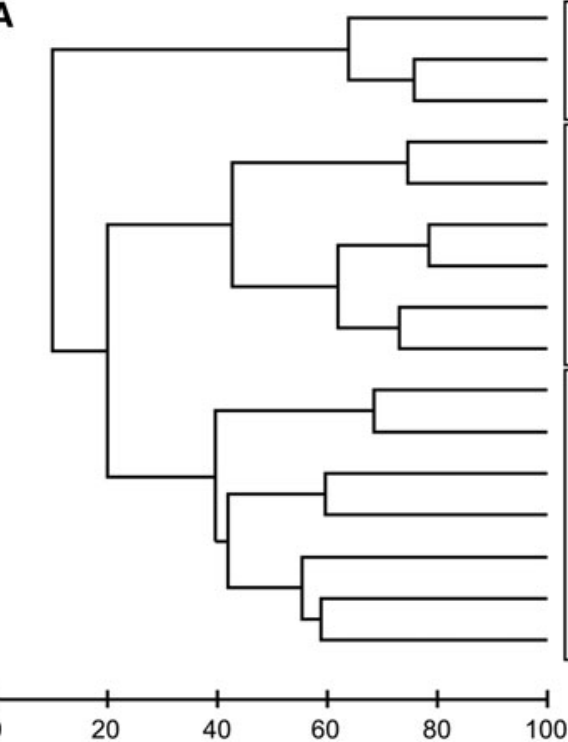

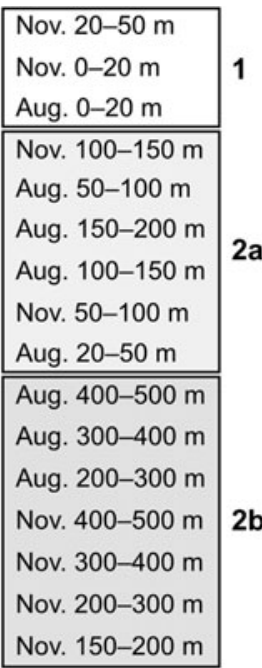

B

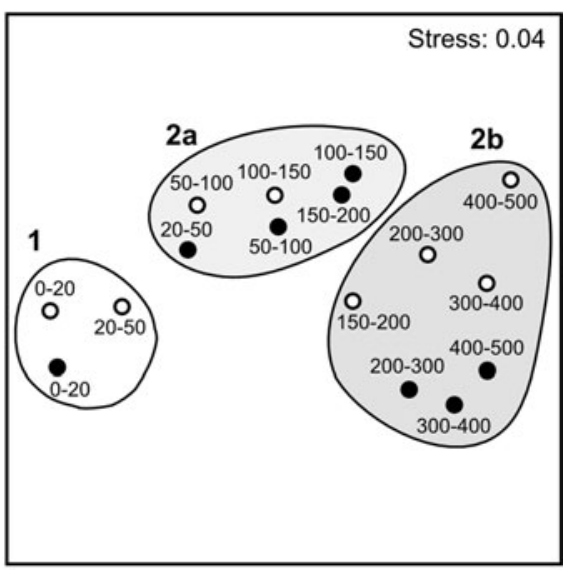

Bray-Curtis similarity (\%)

Fig. 6. (A) Dendrogram for hierarchical clustering of the 16 samples, using group-average linking of Bray-Curtis similarities calculated on log ( +1 ) transformed abundance data of oncaeid copepods in Tosa Bay, 2005. Cluster groups are shown as 1, 2a and 2b; (B) ordination plot of comparison of samples using non-metric multidimensional scaling (MDS) and Bray-Curtis similarities. Cluster groups determined in the panel A are superimposed. Axis scales are relative in MDS plot. Closed and open circles are samples collected in August and November 2005, respectively.

(28 species from 0-1850 m; Böttger-Schnack, 1997) and the Adriatic Sea (22 species from o-80o m; Kršinić \& Grbec, 2002). However, the species number in Tosa Bay is considerably lower as compared to the Arabian Sea, where 69 oncaeids were recorded from the $0-1850 \mathrm{~m}$ water column (Böttger-Schnack, 1996). However, considering that nearly two-thirds of the species were found in the bathypelagic zone below $1000 \mathrm{~m}$ in the Arabian Sea, the number of species for the epipelagic and mesopelagic zones appears to be comparable between the two areas. Thus, a high species richness of the oncaeid copepod community in Tosa Bay (and therefore also in the Kuroshio region) can be concluded from the present study, which amounts to about half the number of known oncaeid species in the world ocean ( 100 species; Böttger-Schnack et al., 2004).

It is noteworthy that three form variants of Oncaea venusta were found in Tosa Bay, which have been observed in the western North Pacific before (Böttger-Schnack, 2001; Böttger-Schnack \& Huys, 2004) and which have recently been assigned to different genetic lineages (Elvers et al., 2006). The different seasonality in occurrence of these variants suggests that the medium form, which occurred only in November, has a different physiology from the large and small forms in both August and November. Such a difference in the temporal distribution pattern of O. venusta form variants was also reported in the Red Sea (Böttger-Schnack, 1990). The occurrence of O. bispinosa in Tosa Bay was also notable, because the records of this species were previously restricted to the northern and equatorial Indian Ocean (Böttger-Schnack, 2002), and thus this species in Tosa Bay is new to the copepod fauna of the Pacific Ocean. Only O. zernovi, a sibling species of O. bispinosa, has previously been recorded from the western North Pacific. Further taxonomic examinations on zernovi-type oncaeids are needed for other areas in the western North Pacific, in order to elucidate their geographical distribution in the Indo-Pacific region.
Of the nine dominant species in the $0-500 \mathrm{~m}$ water column, Oncaea zernovi, O. tregoubovi, Spinoncaea ivlevi and $S$. tenuis were typically small, with body length less than $0.5 \mathrm{~mm}$. These four species and O. bispinosa (a highly abundant species in November), together made up 30-40\% of the total number of adults, indicating the numerical importance of these small-sized species in the oncaeid community. Other small species including O. crypta, O. parabathyalis, O. minima, O. prendeli and O. longipes showed high relative abundances especially in the mesopelagic zone between 200 and $500 \mathrm{~m}$. Numerical dominance of small oncaeid species in the mesopelagic zone has also been reported from other oceanic regions (Böttger-Schnack, 1995, 1996, 1997; Nishibe \& Ikeda, 2004). However, their ecological significance is not understood yet due to a paucity of information about feeding and reproduction (Böttger-Schnack et al., 2004).

In the western North Pacific, available information on the abundance and species composition of oncaeids based on fine-mesh net samples is limited to that from the subarctic Oyashio region (Nishibe \& Ikeda, 2004). Comparing the present results with those in the Oyashio region, abundances in the water column from o to $500 \mathrm{~m}$ are similar between the two areas $\left(64,100-123,600\right.$ ind $\mathrm{m}^{-2}$ in the Oyashio region), although it should be noted that the net mesh used in the study of Nishibe \& Ikeda (2004) was somewhat coarser $(0.1 \mathrm{~mm})$ than the present one $(0.063 \mathrm{~mm})$. With regard to the species composition, 24 out of all oncaeid species found in Tosa Bay have also been reported from the Oyashio region. In the latter region, however, about half of these common species (Triconia conifera, T. minuta, T. umerus, T. parasimilis, T. dentipes, T. giesbrechti, Oncaea venusta, $O$. mediterranea and $O$. media) were assumed to be warm-water immigrants, because they occurred only when the effect of warm-core rings originating from the Kuroshio Extension was evident (Nishibe \& Ikeda, 
2004). Excepting these species from the comparison, it becomes apparent that the common oncaeids between the two areas are mostly restricted to deep-water species, such as O. parila, O. englishi, O. macilenta, O. brodskii, O. longipes, O. tregoubovi, Conaea rapax and Epicalymma spp. These eight taxa probably occur widespread in the deep-water throughout the western North Pacific.

The highest abundances of oncaeid copepods in Tosa Bay corresponded with the depth where appendicularians occurred in high numbers. Previous studies have clearly shown that oncaeid copepods utilize discarded appendicularian houses as both a habitat and as a food source (Alldredge, 1972; Ohtsuka \& Kubo, 1991; Ohtsuka et al., 1993; Steinberg et al., 1994; Ohtsuka et al., 1996). Hence, the depth-distribution pattern of oncaeid copepods in Tosa Bay may partly be determined by that of appendicularians, although the density of discarded houses in the water column was not examined in the present study. The maximum abundances of oncaeids also agree with the depth of high chlorophyll- $a$ concentrations observed. The major components of primary production in Tosa Bay are pico-phytoplankton and nano-phytoplankton (Ichikawa \& Hirota, 2004), which cannot be utilized directly by oncaeids due to their small size $\left(<_{10} \mu \mathrm{m}\right)$. As suggested by Ohtsuka et al. (1996), oncaeids might utilize indirectly such small phytoplankton concentrated on discarded appendicularian houses.

The oncaeid copepod community in Tosa Bay could be differentiated into three distinct groups (Group 1, 2a and $2 b)$, according to the depth layers. Group 1 is the upper epipelagic community, above the seasonal thermocline, and was predominated by Oncaea venusta, O. media and O. waldemari. Group $2 \mathrm{a}$ is the lower epipelagic community, found within or below the thermocline, and was dominated by the smaller oncaeid species, O. scottodicarloi, O. zernovi, O. bispinosa, Spinoncaea ivlevi and S. tenuis. Group $2 \mathrm{~b}$ is the mesopelagic community, below $150 \mathrm{~m}$ or $200 \mathrm{~m}$, where only minimal temperature and salinity gradients were observed. This community is represented by O. crypta, O. parabathyalis, O. minima, O. tregoubovi, O. prendeli, O. longipes and Triconia conifera. This vertical zonation of the oncaeid copepod community seems to be related to the difference in hydrographic conditions in the water column. In particular, the strong separation of the upper epipelagic community from the lower epipelagic and mesopelagic communities, which is clearly shown in the MDS ordination plot, indicates a large influence of the thermocline on vertical structuring of oncaeid assemblages in Tosa Bay.

\section{ACKNDWLEDGEMENTS}

We would like to express our gratitude to Dr R. Böttger-Schnack for her critical comments on an earlier draft of this paper. We thank the captain and crews of RV 'Shirafuji Maru', National Research Institute of Fisheries and Environment of Inland Sea, Fisheries Research Agency, for their help in field samplings. This study was supported partly by the '21st Century COE Program', the Japanese Ministry of Education, Culture, Sports, Science and Technology, at Ehime University.

\section{REFERENCES}

Alldredge A.L. (1972) Abandoned larvacean houses: a unique food source in the pelagic environment. Science 177, 885-887.

Böttger-Schnack R. (1990) Community structure and vertical distribution of cyclopoid copepods in the Red Sea. II. Aspects of seasonal and regional differences. Marine Biology 106, 487-501.

Böttger-Schnack R. (1994) The microcopepod fauna in the Eastern Mediterranean and Arabian Seas: a comparison with the Red Sea fauna. Hydrobiologia 292/293, 271-282.

Böttger-Schnack R. (1995) Summer distribution of micro- and small mesozooplankton in the Red Sea and Gulf of Aden, with special reference to non-calanoid copepods. Marine Ecology Progress Series 118, $81-102$.

Böttger-Schnack R. (1996) Vertical structure of small metazoan plankton, especially non-calanoid copepods. I. Deep Arabian Sea. Journal of Plankton Research 18, 1073-1101.

Böttger-Schnack R. (1997) Vertical structure of small metazoan plankton, especially non-calanoid copepods. II. Deep Eastern Mediterranean (Levantine Sea). Oceanologica Acta 20, 399-419

Böttger-Schnack R. (1999) Taxonomy of Oncaeidae (Copepoda, Poecilostomatoida) from the Red Sea. I. 11 species of Triconia gen. nov. and a redescription of $T$. similis (Sars) from Norwegian waters. Mitteilungen aus dem Hamburgischen Zoologischen Museum und Institut 96, 37-128.

Böttger-Schnack R. (2001) Taxonomy of Oncaeidae (Copepoda, Poecilostomatoida) from the Red Sea. II. Seven species of Oncaea s. str. Bulletin of the Natural History Museum London (Zoology) 67, $25-84$.

Böttger-Schnack R. (2002) Taxonomy of Oncaeidae (Copepoda, Poecilostomatoida) from the Red Sea. VI. Morphology and zoogeography of Oncaea bispinosa sp. nov., a sister taxon of O. zernovi Shmeleva. Journal of Plankton Research 24, 1107-1129.

Böttger-Schnack R. (2003) Taxonomy of Oncaeidae (Copepoda, Poecilostomatoida) from the Red Sea. V. Three species of Spinoncaea gen. nov. (ivlevi-group), with notes on zoogeographical distribution. Zoological Journal of the Linnean Society 137, 187-226.

Böttger-Schnack R. (2005) Taxonomy of Oncaeidae (Copepoda, Poecilostomatoida) from the Red Sea. VII. Oncaea cristata, a new species related to the ovalis-complex, and a revision of $O$. ovalis Shmeleva and O. bathyalis Shmeleva from the Mediterranean. Cahiers de Biolgie Marine 46, 161-209.

Böttger-Schnack R. and Boxshall G.A. (1990) Two new Oncaea species (Copepoda: Poecilostomatoida) from the Red Sea. Journal of Plankton Research 12, 861-871.

Böttger-Schnack R. and Huys R. (2004) Size polymorphism in Oncaea venusta Philippi, 1843 and the validity of $O$. frost $i$ Heron, 2002: a commentary. Hydrobiologia 513, 1-5.

Böttger-Schnack R., Lenz J. and Weikert H. (2004) Are taxonomic details of relevance to ecologists? An example from oncaeid microcopepods of the Red Sea. Marine Biology 144, 1127-1140.

Boxshall G.A. (1977) The depth distributions and community organization of the planktonic cyclopoids (Crustacea: Copepoda) of the Cape Verde Islands region. Journal of the Marine Biological Association of the United Kingdom 57, 543-568.

Boxshall G.A. and Böttger R. (1987) Two new species of Oncaea (Copepoda: Poecilostomatoida) from the Red Sea and a redescription of O. atlantica Shmeleva. Journal of Plankton Research 9, 553-564.

Boxshall G.A. and Halsey S.H. (2004) An introduction to copepod diversity. London: The Ray Society. 
Chen Q.-C., Zhang S.-Z. and Zhu C.-S. (1974) On planktonic copepods of the Yellow Sea and the East China Sea. II. Cyclopoida and Harpacticoida. Studia Marine Sinica 9, 27-76. [In Chinese with English abstract.]

Elvers D., Böttger-Schnack R., Blohm D. and Hagen W. (2006) Sympatric size variants of the microcopepod Oncaea venusta exhibit distinct lineage in DNA sequences. Marine Biology 149, 503-513.

Fujimoto M. (1987) On the flow types and current stability in Tosa Bay and adjacent seas. Umi to Sora 62, 127-140. [In Japanese with English abstract.]

Furuhashi K. (1966) Studies on the vertical distribution of copepods in the Oyashio region east of Japan and in the Kuroshio region south of Japan. Publications of the Seto Marine Biological Laboratory 14 295-322.

Gordeyeva K.T. (1972) New species of the genus Oncaea (Copepoda, Cyclopoida) from the tropical zone of the Atlantic Ocean. Zoologicheskii Zhurnal 51, 963-968. [In Russian with English abstract.]

Gordeyeva K.T. (1973) New species of the genus Oncaea (Copepoda, Cyclopoida) from the tropical Atlantic. Zoologicheskii Zhurnal 54, 1572-1576. [In Russian with English abstract.]

Heron G.A. (1977) Twenty-six species of Oncaeidae (Copepoda: Cyclopoida) from the southwest Pacific Antarctic area. In Pawson D.L. (ed.) Biology of the Antarctic Seas VI, Washington: American Geophysical Union, pp. 37-96. [Antarctic Research Series, no. 26.]

Heron G.A. and Bradford-Grieve J.M. (1995) The marine fauna of New Zealand: pelagic Copepoda: Poecilostomatoida: Oncaeidae. New Zealand Oceanographic Institute Memoir 104, 1-57.

Hirakawa K., Ikeda T. and Kajihara N. (1990) Vertical distribution of zooplankton in Toyama Bay, southern Japan Sea, with special reference to Copepoda. Bulletin of Plankton Society of Japan 37, 111-126.

Hirota Y. (1995) The Kuroshio. Part III. Zooplankton. Oceanography and Marine Biology: an Annual Review 33, 151-220.

Huys R. and Böttger-Schnack R. (2007) Taxonomy of Oncaeidae (Copepoda, Cyclopoida) from the Red Sea. VIII. Morphology and phylogenetic position of Oncaea tregoubovi Shmeleva, 1968 and the closely related O. prendeli Shmeleva, 1966 from the Mediterranean Sea. Mitteilungen aus dem Hamburgischen Zoologischen Museum und Institut 104, 89-127.

Ichikawa T. and Hirota Y. (2004) Seasonal changes of primary productivity in Tosa Bay, Japan. Oceanography in Japan 13, 259-269. [In Japanese with English abstract.]

Itoh H. (1997) Family Oncaeidae. In Chihara M. and Murano M. (eds) An illustrated guide to marine plankton in Japan. Tokyo: Tokai University Press, pp. $978-988$.

Itoh H. and Mizushima T. (1999) Seasonal occurrence of the pelagic poecilostomatoid copepods off Miho Key, Suruga Bay, Japan. Bulletin of Institute of Oceanic Research and Development, Tokai University 20, $113-125$

Itoh H. and Mochioka N. (2005) Plankton net designs for sampling mesoplankton in coastal waters. Science Bulletin of the Faculty of Agriculture, Kyusyu University 60, 179-186. [In Japanese with English abstract.]

Kršinić F. and Malt S.J. (1985) Little known species of small Oncaeidae (Cyclopoida) from the South Adriatic. Journal of Plankton Research 7, $189-199$
Kršinić F. and Grbec B. (2002) Some distributional characteristics of small zooplankton at two stations in the Otranto Strait (Eastern Mediterranean). Hydrobiologia 482, 119-136.

Lo W.-T., Shih C.-T. and Hwang J.-S. (2004) Diel vertical migration of the planktonic copepods at an upwelling station north of Taiwan western North Pacific. Journal of Plankton Research 26, 89-97.

Malt S.J. (1983) Studies on the taxonomy and ecology of the marine copepod genus Oncaea Philippi. PhD thesis. University of London, London, UK.

Minoda T. (1971) Pelagic Copepoda in the Bering Sea and the northwestern North Pacific with special reference to their vertical distribution. Memoir of the Faculty of Fisheries, Hokkaido University 18, 1-74.

Miyata K., Yamashige M. and Sugiura K. (1985) Tosa Bay, I Physics. In Coastal Oceanography Research Committee (ed.) Coastal oceanography of Japanese islands. Tokyo: Tokai University Press, pp. 732-735 [In Japanese.]

Motoda S. (1959) Devices of simple plankton apparatus. Memoir of the Faculty of Fisheries, Hokkaido University 7, 73-94.

Nishibe Y. and Ikeda T. (2004) Vertical distribution, abundance and community structure of oncaeid copepods in the Oyashio region, western subarctic Pacific. Marine Biology 145, 931-941.

Ohtsuka S. and Kubo N. (1991) Larvaceans and their houses as important food for some pelagic copepods. Bulletin of Plankton Society of Japan Special Volume, 535-551.

Ohtsuka S., Kubo N., Okada M. and Gushima K. (1993) Attachment and feeding of pelagic copepods on larvacean houses. Journal of Oceanography 49, 115-120.

Ohtsuka S., Böttger-Schnack R., Okada M. and Onbe T. (1996) In situ feeding habits of Oncaea (Copepoda: Poecilostomatoida) from the upper $250 \mathrm{~m}$ of the central Red Sea, with special reference to consumption of appendicularian houses. Bulletin of Plankton Society of Japan $43,89-105$.

Shmeleva A.A. (1969) Espèces nouvelles du genre Oncaea (Copepoda, Cyclopoida) de la mer Adriatique. Bulletin de l'Institute Océanographique, Monaco 68, 1-28.

Steinberg D.K., Silver M.W., Pilskaln C.H., Coale S.L. and Paduan J.B. (1994) Midwater zooplankton communities on pelagic detritus (giant larvacean houses) in Monterey Bay, California. Limnology and Oceanography 39, 1606-1620.

Tsalkina A.V. (1977) Vertical distribution and diurnal migrations of Cyclopoida (Copepoda) in the waters of the North Trade Winds Current and the Sulu Sea. Polskie Archiwum Hydrobiologii 24, Supplement, $337-362$.

and

Yamaguchi A., Watanabe Y., Ishida H., Harimoto T., Furusawa K., Suzuki S., Ishizaka J., Ikeda T. and Takahashi M.M. (2002) Community and trophic structures of pelagic copepods down to greater depths in the western subarctic Pacific (WEST-COSMIC). Deep-Sea Research I 49, 1007-1025.

\section{Correspondence should be addressed to:} Y. Nishibe Ocean Research Institute, University of Tokyo 1-15-1 Minamidai, Nakano, Tokyo 164-8639, Japan email: nishibe@ori.u-tokyo.ac.jp 